\title{
Components of small area variation in death rates: a method applied to data from Sweden
}

\author{
Ragnar Westerling
}

\begin{abstract}
Study objectives - The study aimed to develop and evaluate a method for small area analysis of different non-random components of the variation in death rates. The method was applied to incidence and mortality data for selected malignant neoplasms in 26 administrative health areas in Sweden.
\end{abstract}

Design-Variation in mortality and incidence rates for malignant neoplasms of the trachea, bronchus, and lung; colon; rectum; and cervix uteri in the 26 health areas were analysed after standardisation for age. In addition, the systematic and random components of variance were estimated. The systematic component of variance in mortality was divided into two additive components - one component was dependent on the variation in the corresponding incidence rates and the other remained after adjustment for incidence. Setting and participants - All cases diagnosed between 1972 and 1983 and all deaths between 1974 and 1985 for selected malignant neoplams in Swedish citizens and other residents in Sweden, aged between 0 and 64 years, were analysed.

Main results - Much of the observed variation in mortality was explained by the estimated random variation. For malignant neoplasms of the trachea, bronchus, and lung the systematic variation in mortality was mainly explained by the variation in incidence. For cancer of the cervix uteri, alone, there was significant systematic variation of moderate magnitude that was not explained by the incidence rates.

Conclusions - These methods made it possible to divide the observed variance in mortality into different components. Random effects and variance in incidence rates were found to be of great importance when analysing the variance in death rates between health areas. By studying different systematic components of variation it is possible to identify fields for in depth studies on the quality of prevention and treatment.

( $\mathcal{F}$ Epidemiol Community Health 1995;49:214-221)

Community health information systems have been developed for different purposes, such as monitoring health status, providing warning systems to identify specific health problems, and improving the possibilities for health care evaluation. ${ }^{1}$ The information is often based on official health statistics, for instance data on mortality and incidence.

Several studies have analysed the regional pattern of mortality or incidence of disease. ${ }^{2}$ The statistical problems involved in analysing variation between small geographical areas have been emphasised. ${ }^{3}$ The concept of small area variation has been developed and applied to surgical operating rates ${ }^{4-6}$ but it can also be applied to death rates ${ }^{7}$ and to incidence rates.

The variability between areas has often been studied by identifying the highest and lowest rates $^{39}$ : the size of the ratio of these extreme values, the extremal quotient, has been the basis for statements about the magnitude of the variation. This measure has, however, been found to be particularly unstable. ${ }^{59}$ Random factors may have a considerable effect. Efforts have been made therefore to measure the variation between all areas, not only those with extreme values, and to take into account the influence of random variation. ${ }^{45}$ The question is: Is there more variation between areas than can be explained by random factors and, if so, what is the size of the systematic variation? ${ }^{3}$

During the 1970s and 1980s the methodology for studying avoidable mortality was introduced and applied in several studies. ${ }^{10-15}$ A number of causes of death have been selected as indicators of avoidable mortality based on judgements about whether the conditions are amenable to intervention by health care..$^{13-15}$ According to the avoidable mortality concept, an agglomeration of deaths from these conditions is a warning signal, and this motivated in depth studies on the quality of care. Studies on regional variation in avoidable mortality have been published from different countries. ${ }^{10-14}$

In addition to possible random effects, the death rate for a particular cause of death in an area can be influenced by the corresponding incidence rate in that area. If all systematic variation in death rates can be explained by variation in incidence rates, then death rates provide no additional information beyond that given by incidence rates.

In Sweden and in other Nordic countries, data on cancer incidence ${ }^{16}$ as well as on mortality $^{17}$ are readily available for different administrative health areas. This makes it possible to analyse whether systematic variation in death rates can be explained by variation in incidence.

The incidence rate is thus a potential 
explanatory variable for the death rates. The small area methodology has not, however, been fully developed to estimate both the effect of random variation and the effect of an explanatory variable on the variation. A way of analysing different systematic components of small area variation is therefore called for.

This study aimed to adapt and further develop one method for small area analysis of different systematic components of the variation in death rates. The method is also applied to incidence and mortality data for selected malignant neoplasms in administrative health areas in Sweden and the usefulness of some of the suggested indicators of avoidable mortality are discussed.

\section{Methods}

According to Swedish regulations, all newly diagnosed cases of primary cancer must be notified to the National Cancer Registry by the clinician and by the pathologist/cytologist separately. ${ }^{16}$ The Swedish cause of death register is based upon the death certificates issued by doctors after all deaths of Swedish citizens and other residents in Sweden. ${ }^{17}$

Data on the number of newly diagnosed cases of malignant neoplasms of the colon, rectum, trachea, bronchus, and lung; and invasive cancer of the cervix uteri were collected from the National Cancer Registry and data on the same conditions were gathered from the cause of death registry. These cases were chosen since they were suggested by Rutstein et $a l^{15}$ to be indicators of avoidable mortality, and since they are relatively common in Sweden. ${ }^{18}$

Medical care in Sweden is the responsibility of 26 administrative areas of different sizes (23 counties and three municipalities). Data were available for each of the health areas. The data were given by age and sex for the years 1972-83 (incidence data) and 1974-85 (mortality data). The period chosen for the incidence data in this study preceded the period for the mortality data for most neoplasms; not more, however, than the median time between diagnosis and death as shown by survival statistics. ${ }^{1920}$ (For malignant neoplasms of the lung, however, the median time has been found to be shorter than for the other selected neoplasms, by about one year. ${ }^{1920}$ ) Incidence data for the two, six year periods $1972-77$ and 1978-83 were analysed together with mortality data for the six year periods 1974-79 and 1980-85 respectively. (For malignant neoplasms of the trachea, bronchus, and lung, analyses were also performed for the same time periods as for incidence and mortality data.)

The diagnoses were coded according to the International Classification of Diseases. The registration in the cancer registry was mainly according to ICD- $7^{16}$ whereas the causes of death were coded according to ICD-8. ${ }^{17}$ (Sweden did not introduce ICD-9 until 1987.) ICD7 codes were transformed to ICD- 8 codes. Data on the stage of the disease is not available in the Swedish cancer registry.

The registration deficit in the cancer registry has been estimated to be about $4 \% .^{21}$ The regional differences shown in validity studies are mainly the result of variations in diagnostic intensity for older age groups. For ages under 65 , which were used in this study, these differences are considered to be small. ${ }^{22}$ The validity of causes of death has been shown to be fairly good in younger age groups and for malignant neoplasms. ${ }^{2324}$

Population data were taken from the registers mentioned and from the National Bureau of Statistics. The incidence rates and the death rates were calculated for the different health areas and were standardised in relation to age, with the age specific rates for the whole of Sweden as a standard (indirect standardisation). The analysis was confined to the age group 0-64 years. The annual mean population in the different areas in this age group for the period 1974-85 varied between 45886 and 1309870 .

\section{STATISTICS}

The null hypothesis, that is, that there was no significant systematic variation, was tested using a $\chi^{2}$ test with $\mathrm{k}-1$ degrees of freedom $(\mathrm{k}=$ number of areas analysed, that is 26$).{ }^{525}$ For nearly all the areas (25-26 out of 26 areas) the expected number of deaths from each selected cause of death was at least 5 . The $\chi^{2}$ test should therefore be valid. ${ }^{25}$

The level of the observed variance was calculated by dividing the $\chi^{2}$ values by the number of deaths (n) studied for each type of neoplasm, thus:

$$
\sum_{i=1}^{k} \frac{\left(o_{i}-e_{i}\right)^{2} / e_{i}}{n}
$$

where $o_{i}$ is the observed number of cases and $e_{i}$ the expected number of deaths in each area, based on age specific death rates for the whole of Sweden. These values were assumed to be available from each of the $k$ areas. Since the $\chi^{2}$ values were divided by the total number of deaths ( $n)$, the scale of the measure was the same regardless of the number of deaths. The total number of deaths was, by definition, equal to the sum of the expected number of deaths which is equal to the sum of the observed number of deaths.

The population size varied greatly between the health areas. The expected number of deaths was, by definition, proportional to the population in the study area. As shown in formula (2) the observed variance was equal to the variance of the ratio between the observed numbers (o) and the expected numbers (e) around the value 1 , with the expected values in each area $\left(e_{i}\right)$ as weight. Thus, the observed variance has been weighted proportionally to the population size of the different areas.

$$
\sum_{i=1}^{k} \frac{\left(o_{i}-e_{i}\right)^{2} / e_{i}}{n}=\sum_{i=1}^{k} \frac{e_{i}\left(o_{i} / e_{i}-1\right)^{2}}{n}
$$

The observed variance could be split into two additive components, namely the random 
variance and the systematic variance. When the null hypothesis is true - that is, that there is no systematic variation, all the observed variation is a result of random variation. Assuming the null hypothesis the mathematical expectation of the $\chi^{2}$ distribution is the degree of freedom of the distribution. Therefore, the numerator of the random variation was estimated as the number of the degree of freedom $(k-1)$ of the $\chi^{2}$ distribution. Thus, the random component of the variance was defined as:

$$
\frac{\mathrm{df}}{\mathrm{n}}=\frac{(\mathrm{k}-1)}{\mathrm{n}}
$$

The systematic component of the variance was obtained as the observed variance minus the random variance - that is:

$$
\sum_{i=1}^{k} \frac{\left(o_{i}-e_{i}\right)^{2} / e_{i}}{n}-\frac{(k-1)}{n}
$$

The proportion of the systematic component of the total variance was analysed by dividing the systematic variance (4) with the observed variance (1).

Similar analysis was carried out for death rates as well as for incidence rates.

The division into a systematic and a random component of variance is analogous to the method proposed by McPherson et al. ${ }^{4}$ The formulae differ somewhat, since in this study the observed variance was weighted according to the population size of the different areas.

To estimate different components of variation, generalised linear models were analysed (GLIM analyses). ${ }^{2627}$ These analyses provide maximum likelihood estimates for regression coefficients in the model. The GLIM analyses also provide $\chi^{2}$ values for the test of goodness of fit for the model. These $\chi^{2}$ values were included in the formula for systematic variance (4).

In the first step, the observed and expected number of deaths were the only variables in- cluded in the analyses. Poisson based GLIM analyses were used since the events included in the analyses were rare - that is, occur at a low rate in the study population. In this case the $\chi^{2}$ values were unaltered by the model

In a second step, the corresponding incidence ratios (expressed as the observed number of cases divided by expected number of cases) were included as an independent variable in the GLIM analysis. When the adjustment for incidence improved the prediction of the observed numbers of death, the $\chi^{2}$ value of goodness of fit of the model was reduced. This means that the estimates of the variance were also altered based on the $\chi^{2}$ analysis produced by the GLIM system.

The adjusted $\chi^{2}$ values were included in the formula for systematic variance. In this case the prediction of the observed values was based on two variables ${ }^{25}$ and the degree of freedom was $k-2$. The numerator in the formula for the expected random variance (3) was changed to this value. The corresponding change was made in the numerator of the formula for the systematic variation. The new estimate of the systematic variation was defined as the incidence adjusted systematic component of variance in death rates.

The $\chi^{2}$ values were also the basis for the $\chi^{2}$ test $(\mathrm{df}=k-2)$ to decide whether the systematic variation was significant after adjustment for incidence.

The total systematic variance in death rates minus the incidence adjusted systematic component of variance in death rates was defined as the incidence related systematic component of variance in death rates.

The calculations were performed using the Statistical Analysis System ${ }^{29}$ and the GLIM system package. ${ }^{28}$

\section{Results}

Table 1 shows the annual mean incidence rates (per 100000 ) for 1972-77 and 1978-83, and

Table 1 The mean incidence rates (per 100 000) 1972-77 and 1978-83, and mean death rates (per 100000) 1974-79 and 1980-85 for some

\begin{tabular}{|c|c|c|c|c|c|c|c|c|c|}
\hline \multirow[b]{2}{*}{$\begin{array}{l}\text { ICD-8 } \\
\text { code }\end{array}$} & \multirow[b]{2}{*}{ Diagnosis } & \multicolumn{4}{|c|}{$\begin{array}{l}\text { Period } 1 \\
\text { Death rate 1974-79 } \\
\text { Incidence rate 1972-77 }\end{array}$} & \multicolumn{4}{|c|}{$\begin{array}{l}\text { Period } 2 \\
\text { Death rate } 1980-85 \\
\text { Incidence rate } 1978-83\end{array}$} \\
\hline & & $\begin{array}{l}\text { No of } \\
\text { new cases }\end{array}$ & $\begin{array}{l}\text { Incidence } \\
\text { rate }\end{array}$ & $\begin{array}{l}\text { No of } \\
\text { deaths }\end{array}$ & $\begin{array}{l}\text { Death } \\
\text { rate }\end{array}$ & $\begin{array}{l}\text { No of } \\
\text { new cases }\end{array}$ & $\begin{array}{l}\text { Incidence } \\
\text { rate }\end{array}$ & $\begin{array}{l}\text { No of } \\
\text { deaths }\end{array}$ & $\begin{array}{l}\text { Death } \\
\text { rate }\end{array}$ \\
\hline $\begin{array}{l}\text { Males: } \\
153\end{array}$ & $\begin{array}{l}\text { Malignant neoplasms } \\
\text { of large intestine, } \\
\text { except rectum }\end{array}$ & 1961 & $9 \cdot 25$ & 1072 & $5 \cdot 06$ & 1974 & $9 \cdot 33$ & 973 & $4 \cdot 61$ \\
\hline 154 & $\begin{array}{l}\text { except rectum } \\
\text { Malignant neoplasms } \\
\text { of rectum and } \\
\text { rectosigmoid junction }\end{array}$ & 1432 & $6 \cdot 76$ & 658 & $3 \cdot 10$ & 1462 & $6 \cdot 91$ & 605 & $2 \cdot 87$ \\
\hline 162 & $\begin{array}{l}\text { Malignant neoplasms } \\
\text { of trachea, bronchus } \\
\text { and lung }\end{array}$ & 3597 & $16 \cdot 97$ & 3202 & $15 \cdot 11$ & 3729 & $17 \cdot 63$ & 3218 & $15 \cdot 25$ \\
\hline Females: & Malignant neoplasms & 2165 & $10 \cdot 53$ & 1065 & $5 \cdot 18$ & 2236 & $10 \cdot 88$ & 993 & $4 \cdot 84$ \\
\hline 154 & $\begin{array}{l}\text { of large intestine, } \\
\text { except rectum } \\
\text { Malignant neoplasms } \\
\text { of rectum and }\end{array}$ & 1115 & $5 \cdot 42$ & 456 & $2 \cdot 22$ & 1197 & $5 \cdot 83$ & 443 & $2 \cdot 16$ \\
\hline 162 & $\begin{array}{l}\text { rectosigmoid junction } \\
\text { Malignant neoplasms } \\
\text { of trachea, bronchus } \\
\text { and lung }\end{array}$ & 1044 & $5 \cdot 08$ & 994 & $4 \cdot 83$ & 1436 & $6 \cdot 99$ & 1347 & $6 \cdot 57$ \\
\hline 180 & $\begin{array}{l}\text { Malignant neoplasms } \\
\text { of cervix uteri }\end{array}$ & 2779 & $13 \cdot 52$ & 839 & $4 \cdot 08$ & 2292 & $11 \cdot 16$ & 634 & 3.09 \\
\hline
\end{tabular}
malignant neoplasms in Sweden for ages 0-64 years in relation to gender 
Table 2 The observed and expected number of new cases of invasive cancer of the cervix 1978-83 and the observed and expected number of deaths and relative risk (RR) values in 1980-85 for ages 0-64 years among health areas in Sweden

\begin{tabular}{|c|c|c|c|c|c|}
\hline $\begin{array}{l}\text { Health } \\
\text { area }\end{array}$ & $\begin{array}{l}\text { Expected no } \\
\text { of cases }\end{array}$ & $\begin{array}{l}\text { No of } \\
\text { cases }\end{array}$ & $\begin{array}{l}\text { Expected no } \\
\text { of deaths }\end{array}$ & $\begin{array}{l}\text { No of } \\
\text { deaths }\end{array}$ & $\begin{array}{l}R R \text { for } \\
\text { deaths }\end{array}$ \\
\hline Södermanland & 69 & 75 & 19 & 30 & $1 \cdot 57$ \\
\hline Göteborg & 123 & 128 & 34 & 53 & 1.56 \\
\hline Gävleborg & 81 & 97 & 23 & 29 & $1 \cdot 27$ \\
\hline Blekinge & 41 & 38 & 12 & 15 & $1 \cdot 25$ \\
\hline Gotland & 15 & 16 & 4 & 5 & $1 \cdot 25$ \\
\hline Västernorrland & 74 & 77 & 21 & 26 & $1 \cdot 24$ \\
\hline Stockholm & 439 & 494 & 120 & 141 & $1 \cdot 18$ \\
\hline Kopparberg & 78 & 77 & 22 & 26 & $1 \cdot 18$ \\
\hline Malmöhus & 140 & 170 & 38 & 44 & $1 \cdot 16$ \\
\hline Värmland & 78 & 89 & 22 & 25 & $1 \cdot 12$ \\
\hline Örebro & 75 & 78 & 21 & 22 & 1.05 \\
\hline Halland & 62 & 54 & 17 & 18 & 1.03 \\
\hline Malmö kommun & 67 & 94 & 19 & 17 & 0.88 \\
\hline Jämtland & 37 & 40 & 10 & 9 & $0 \cdot 86$ \\
\hline Norrbotten & 73 & 49 & 20 & 17 & 0.85 \\
\hline Älvsborg & 115 & 100 & 32 & 26 & $0 \cdot 82$ \\
\hline Kristianstad & 75 & 66 & 21 & 17 & $0 \cdot 80$ \\
\hline Göteborg o Bohus & 78 & 71 & 21 & 17 & 0.80 \\
\hline Skaraborg & 71 & 52 & 20 & 16 & $0 \cdot 80$ \\
\hline Kronoberg & 46 & 37 & 13 & 10 & 0.78 \\
\hline Östergötland & 107 & 96 & 30 & 21 & 0.71 \\
\hline Västmanland & 72 & 85 & 20 & 14 & 0.71 \\
\hline Västerbotten & 67 & 54 & 19 & 13 & $0 \cdot 70$ \\
\hline Jönköping & 81 & 52 & 23 & 10 & 0.44 \\
\hline Uppsala & 66 & 67 & 17 & 7 & 0.41 \\
\hline Kalmar & 65 & 36 & 18 & 6 & 0.33 \\
\hline Total & 2292 & 2292 & 634 & 634 & 1.00 \\
\hline
\end{tabular}

the annual mean death rates (per 100000) for 1974-79 and 1980-85 in health areas in Sweden. The mean incidence rates for the two periods were relatively close. For malignant neoplasms of the trachea, bronchus, and lung, however, the female incidence rate was $38 \%$ higher in the second period. For invasive neoplasms of cervix uteri, the incidence rate in the second period was $17 \%$ lower than that in the first period. In most cases the death rates in the second period were somewhat lower. For malignant neoplasms of the trachea, bronchus, and lung, however, the death rate in women was $36 \%$ higher in the second period. For cervical cancer the death rate in the second period was $24 \%$ lower than in the first period.

The basic data from different health areas in the second period included in the study are given in table 2 . This shows the observed and expected number of new cases of invasive cancer of the cervix in 1978-83 and the observed and expected numbers of deaths and relative risks (RR) for this disease during the period 1980-85. The expected number of new cases varied between 15 and 439 and the expected number of deaths between 4 and 120 . The RR values varied between 0.3 and 1.6 between the different health areas.

The estimates of the systematic component of variance in RR for incidence are shown in table 3. For most neoplasms the variation was significant. That part of the observed variance attributable to the systematic components varied between $24 \%$ and $95 \%$.

The highest systematic variance obtained was for cancer of trachea, bronchus, and lung (vari-

Table 3 The systematic component of variance in relative risk for incidence rates in some malignant neoplasms between health areas in Sweden for ages 0-64 years, 1972-77 and 1978-83, in relation to gender

\begin{tabular}{|c|c|c|c|c|c|c|c|c|c|}
\hline \multirow[b]{2}{*}{$\begin{array}{l}\text { ICD-8 } \\
\text { code }\end{array}$} & \multirow[b]{2}{*}{ Diagnosis } & \multicolumn{4}{|l|}{$1972-77$} & \multicolumn{4}{|l|}{$1978-83$} \\
\hline & & Variance & $\begin{array}{l}\text { Systematic } \\
\text { component } \\
\text { of } \\
\text { variance }\end{array}$ & $\begin{array}{l}\text { Proportion } \\
\text { for the } \\
\text { systematic } \\
\text { component }\end{array}$ & p value & Variance & $\begin{array}{l}\text { Systematic } \\
\text { component } \\
\text { of } \\
\text { variance }\end{array}$ & $\begin{array}{l}\text { Proportion } \\
\text { for the } \\
\text { systematic } \\
\text { component }\end{array}$ & $p$ value \\
\hline \multicolumn{10}{|c|}{$\begin{array}{ll}\text { Males: } & \\
153 \text { Malignant neoplasms } \\
\text { of large intestine, } \\
\text { except rectum }\end{array}$} \\
\hline 154 & $\begin{array}{l}\text { Malignant neoplasms } \\
\text { of rectum and } \\
\text { rectosigmoid junction }\end{array}$ & 0.041 & 0.023 & 0.572 & $* * *$ & 0.036 & 0.019 & 0.528 & $* * *$ \\
\hline 162 & $\begin{array}{l}\text { Malignant neoplasms } \\
\text { of trachea, bronchus, } \\
\text { and lung }\end{array}$ & 0.092 & 0.085 & 0.994 & $* * *$ & 0.077 & 0.070 & 0.913 & $* * *$ \\
\hline \multicolumn{10}{|c|}{ Females: } \\
\hline 153 & $\begin{array}{l}\text { Malignant neoplasms } \\
\text { of large intestine, } \\
\text { except rectum }\end{array}$ & 0.022 & 0.011 & 0.480 & $* *$ & 0.017 & 0.006 & $0 \cdot 341$ & $*$ \\
\hline 154 & $\begin{array}{l}\text { Malignant neoplasms } \\
\text { of rectum and } \\
\text { rectosigmoid junction }\end{array}$ & 0.036 & $0 \cdot 013$ & 0.376 & $*$ & 0.027 & 0.007 & $0 \cdot 246$ & - \\
\hline 162 & $\begin{array}{l}\text { Malignant neoplasms } \\
\text { of trachea, bronchus, } \\
\text { and lung }\end{array}$ & 0.094 & 0.070 & 0.950 & $* * *$ & 0.078 & 0.061 & 0.777 & $* * *$ \\
\hline 180 & $\begin{array}{l}\text { Malignant neoplasms } \\
\text { of cervix uteri }\end{array}$ & 0.046 & 0.037 & $0 \cdot 805$ & $* * *$ & 0.032 & 0.021 & 0.662 & $* * *$ \\
\hline
\end{tabular}

${ }_{*}^{*} \mathrm{p}$ value $<0.05$

${ }_{* * *}^{* *}$ value $<0.01$ 
Table 4 The systematic component of variance in relative risk of mortality from some malignant neoplasms in health areas in Sweden for ages 0-64 years, 1974-79 and 1980-85, in relation to gender

\begin{tabular}{|c|c|c|c|c|c|c|c|c|c|}
\hline \multirow[b]{2}{*}{$\begin{array}{l}\text { ICD-8 } \\
\text { code }\end{array}$} & \multirow[b]{2}{*}{$\begin{array}{l}\text { Cause of } \\
\text { death }\end{array}$} & \multicolumn{4}{|l|}{$1974-79$} & \multicolumn{4}{|l|}{$1980-85$} \\
\hline & & Variance & $\begin{array}{l}\text { Systematic } \\
\text { component } \\
\text { of } \\
\text { variance }\end{array}$ & $\begin{array}{l}\text { Proportion } \\
\text { for the } \\
\text { systematic } \\
\text { component }\end{array}$ & $p$ value & Variance & $\begin{array}{l}\text { Systematic } \\
\text { component } \\
\text { of } \\
\text { variance }\end{array}$ & $\begin{array}{l}\text { Proportion } \\
\text { for the } \\
\text { systematic } \\
\text { component }\end{array}$ & $p$ value \\
\hline $\begin{array}{l}\text { Males: } \\
153\end{array}$ & $\begin{array}{l}\text { Malignant neoplasms } \\
\text { of large intestine, } \\
\text { except rectum }\end{array}$ & 0.020 & $0 \cdot 000$ & $0 \cdot 000$ & - & $0 \cdot 022$ & 0.000 & $0 \cdot 000$ & - \\
\hline 154 & $\begin{array}{l}\text { Malignant neoplasms } \\
\text { of rectum and } \\
\text { rectosigmoid junction }\end{array}$ & 0.051 & $0 \cdot 013$ & $0 \cdot 258$ & - & $0 \cdot 033$ & 0.000 & $0 \cdot 000$ & - \\
\hline 162 & $\begin{array}{l}\text { Malignant neoplasms } \\
\text { of trachea, bronchus, } \\
\text { and lung }\end{array}$ & 0.076 & $0 \cdot 069$ & $0 \cdot 898$ & $* * *$ & 0.059 & 0.051 & $0 \cdot 868$ & $* * *$ \\
\hline \multicolumn{10}{|c|}{ Females: } \\
\hline 153 & $\begin{array}{l}\text { Malignant neoplasms } \\
\text { of large intestine, } \\
\text { except rectum }\end{array}$ & $0 \cdot 030$ & $0 \cdot 007$ & $0 \cdot 231$ & - & 0.037 & 0.012 & 0.314 & - \\
\hline 154 & $\begin{array}{l}\text { Malignant neoplasms } \\
\text { of rectum and } \\
\text { rectosigmoid junction }\end{array}$ & 0.062 & 0.007 & $0 \cdot 116$ & - & $0 \cdot 056$ & $0 \cdot 000$ & $0 \cdot 000$ & - \\
\hline 162 & $\begin{array}{l}\text { Malignant neoplasms } \\
\text { of trachea, bronchus, } \\
\text { and lung }\end{array}$ & $0 \cdot 088$ & 0.063 & $0 \cdot 715$ & $* * *$ & 0.065 & $0 \cdot 046$ & $0 \cdot 714$ & $* * *$ \\
\hline 180 & $\begin{array}{l}\text { Malignant neoplasms } \\
\text { of cervix uteri }\end{array}$ & $0 \cdot 079$ & $0 \cdot 049$ & $0 \cdot 622$ & $* * *$ & $0 \cdot 094$ & $0 \cdot 054$ & $0 \cdot 579$ & $* * *$ \\
\hline
\end{tabular}

$*$ p value $<0.05$

*** $\mathrm{p}$ value $<0 \cdot 001$

Table 5 Different systematic components of variance in relative risk of mortality from malignant neoplasms of the trachea, bronchus, and lung and of cervix uteri between health areas in Sweden for ages 0-64 years in relation to gender

\begin{tabular}{|c|c|c|c|c|c|c|c|}
\hline \multirow[b]{2}{*}{$\begin{array}{l}\text { ICD-8 } \\
\text { code }\end{array}$} & \multirow[b]{2}{*}{ Diagnosis } & \multicolumn{3}{|c|}{$\begin{array}{l}\text { Period } 1 \\
\text { Death rate } 1974-79 \\
\text { Incidence rate } 1972-77\end{array}$} & \multicolumn{3}{|c|}{$\begin{array}{l}\text { Period } 2 \\
\text { Death rate } 1980-85 \\
\text { Incidence rate } 1978-83\end{array}$} \\
\hline & & $\begin{array}{l}\text { Total } \\
\text { systematic } \\
\text { variance } \\
\text { in } \\
\text { mortality }\end{array}$ & $\begin{array}{l}\text { Incidence- } \\
\text { adjusted } \\
\text { systematic } \\
\text { component } \\
\text { of variance } \\
\text { in mortality }\end{array}$ & $\begin{array}{l}\text { Incidence- } \\
\text { related } \\
\text { systematic } \\
\text { component } \\
\text { of variance } \\
\text { in mortality }\end{array}$ & $\begin{array}{l}\text { Total } \\
\text { systematic } \\
\text { variance } \\
\text { in mortality }\end{array}$ & $\begin{array}{l}\text { Incidence- } \\
\text { adjusted } \\
\text { systematic } \\
\text { component } \\
\text { of variance } \\
\text { in mortality }\end{array}$ & $\begin{array}{l}\text { Incidence- } \\
\text { related } \\
\text { systematic } \\
\text { component } \\
\text { of variance } \\
\text { in mortality }\end{array}$ \\
\hline $\begin{array}{l}\text { Males: } \\
162\end{array}$ & $\begin{array}{l}\text { Malignant neoplasms } \\
\text { of trachea, bronchus, } \\
\text { and lung }\end{array}$ & 0.069 & 0.002 & $0 \cdot 067^{* * *}$ & $0 \cdot 051$ & 0.002 & $0.049^{* * *}$ \\
\hline $\begin{array}{l}\text { Females } \\
162\end{array}$ & $\begin{array}{l}\text { Malignant neoplasms } \\
\text { of trachea, bronchus, }\end{array}$ & 0.063 & 0.015 & $0.048^{* * *}$ & $0 \cdot 046$ & 0.000 & $0 \cdot 046^{* * *}$ \\
\hline 180 & $\begin{array}{l}\text { and lung } \\
\text { Malignant neoplasms } \\
\text { of cervix uteri/ } \\
\text { invasive cancer }\end{array}$ & 0.049 & $0.016^{*}$ & $0.033^{*}$ & 0.054 & $0 \cdot 027^{*}$ & $0.027^{*}$ \\
\hline
\end{tabular}

Level of significance:

$*$ p value $<0.05$

${ }_{* * *}$ p value $<0.01$

${ }^{* * *}$ p value $<0.001$

ance between 0.061 and 0.085 ). The corresponding $\mathrm{SD}$ is the square root of the variance which is equal to between $25 \%$ and $29 \%$. The variation found in this case was therefore considerable.

The systematic component of variance in $R R$ for mortality from these different causes of death in 1974-79 and 1980-85 is shown in table 4 . The highest systematic variance was for malignant neoplasms of the trachea, bronchus and lung and for malignant neoplasms of the cervix uteri. For these two conditions the variation was significant.

For cancer of cervix uteri the systematic variance was estimated to be 0.049 and 0.054 , which corresponds to a considerable SD, $22 \%$ and $23 \%$. For malignant neoplasma of trachea, bronchus, and lung the systematic variance was between 0.046 and 0.069 and the corresponding estimated SD between $21 \%$ and $26 \%$.
For malignant neoplasms of the colon and rectum, however, the systematic $\mathrm{SD}$ was low, between 0 and $12 \%$.

For malignant neoplasms of the trachea, bronchus, and lung and the cervix uteri the systematic variance accounted for the greater part (between 58 and $90 \%$ ) of the observed variance. In the other neoplasms the systematic component accounted for between $0 \%$ and about $30 \%$ of the variance. In the case of these neoplasms the observed variance therefore seems to be more attributable to random effects than to systematic variation.

For most neoplasms the systematic variance in death rates was lower after adjustment for incidence. For malignant neoplasms of the colon and rectum the already low systematic variance was adjusted to zero or close to zero. For cancer of the colon among women in the second period, however, the adjustment was small (systematic variance 0.012 
before adjustment and 0.011 after adjustment).

For malignant neoplasms of the trachea, bronchus, and lung and of the cervix uteri different systematic components of the variance in mortality were analysed. In table 5 the total systematic variance in mortality is divided into the incidence adjusted and the incidence related systematic components of the variance in mortality (the different components were defined in methods).

For cancer of the trachea, bronchus, and lung the systematic variance in mortality seems to be mainly dependent on the variation in incidence. The incidence related component of variance in mortality was significant and varied between 0.047 and 0.066 (table 5).

In table 5 the period for the incidence data preceded the period for the mortality data. In further analyses for malignant neoplasms of the trachea, bronchus, and lung, the systematic variances in mortality were adjusted by the incidence rates from the same time periods. In this case, for the first period all the systematic variance in mortality and for the second period nearly all the systematic component of variance $(0.047$ out of 0.051 for men and 0.042 out of 0.046 for women) was explained by the variation in incidence rates.

The variance for cancer of the cervix uteri was adjusted by the incidence ratios for invasive cancer. The systematic variance was lower after this adjustment. Both the systematic components were significant.

\section{Discussion \\ A METHOD FOR ANALYSIS OF SMALL AREA VARIATION}

In this study the variations in death rates between the 26 health areas in Sweden were analysed for some causes of death. The numbers of cancer cases and deaths included in the analysis were relatively small in many areas. Different statistical methods for small area analysis have been suggested. ${ }^{4-6}$ In this study the methods have been developed and combined in a new way.

The null hypothesis suggesting that there was no variation in death rates in the different areas was tested. As suggested by Diehr et al, ${ }^{5}$ a $\chi^{2}$ test was used - that is, the traditional test of heterogeneity. A new approach was that the corresponding weighted systematic variance was also estimated. Estimates of this type may be of use in many situations, for instance as a descriptive measure and when making comparisons between different time periods and diseases. Systematic variation may also be of interest, even if it does not reach significance, if the variation is concentrated in certain areas. This information would be useful when the avoidable mortality concept is applied - that is when screening for high death rates in some areas. ${ }^{1518}$

The term "small area analysis" suggests that the main point of the method is that the population in the study areas is small. The method should, however, be applicable whenever the variation for rare events is studied. In this study it was found that a considerable part of the variation in death rates for selected causes could be a result of expected random variation. The concept of small area analysis seems therefore to be appropriate.

The incidence adjusted systematic variance was estimated using GLIM analyses. ${ }^{2627}$ The systematic component of variance was shown to be sensitive to adjustment for incidence rates, for which a fairly large proportion of the variation was found to be systematic. As expected, the incidence adjusted systematic variation generally had lower values than the unadjusted systematic variation.

THE USEFULNESS OF THE DIFFERENT MORTALITY INDICATORS

The results of the analysis give indications of areas of interest for further studies at the community level as well as for individual cases.

For some of the neoplasms, for instance for cancer of the rectum and for cancer of the colon in men, virtually all the variation in mortality was explained by the expected random variation and by the corresponding variation in incidence rates. Death rates for these conditions were suggested by Rutstein et $a l^{7}$ to be indicators of the outcome of treatment measures.

In this study, it was not possible to include data on the cancer stage of the newly diagnosed cases, and, therefore, it is not possible to judge whether there was variation in the effect of treatments. For cancer of the rectum and colon, however, the results show that variation in death rates among health areas in Sweden did not provide any information in addition to incidence and random effects. Thus, the death rates from these conditions were not useful as indicators of the quality of care in Swedish health areas.

For cancer of the trachea, bronchus, and lung there was a significant systematic variation in mortality that was mainly explained by the variation in incidence. High death reates for this condition have been suggested to be warning signals motivating in depth studies of the quality of the primary prevention. ${ }^{13-15}$ In this study it was found that high death rates for cancer of the trachea, bronchus, and lung were strongly related to high incidence rates. Attention should be paid to preventive programmes ${ }^{30}$ that can change the variation in incidence. ${ }^{31}{ }^{32}$ Incidence data may also provide earlier warning signals than mortality data. The optimal interval between the time periods for incidence and mortality data may vary between different diseases. In the first period, there was a slightly greater correlation between incidence and mortality for malignant neoplasms of the trachea, bronchus, and lung when the same time period was used for both these two measures. This is to be expected, since the survival time for cancer of the lung has been shown to be short. ${ }^{190}$

For malignant neoplasms of the trachea, bronchus, and lung it may be possible to study community health indicators further. Rosén 
et al have suggested regional analysis of the consistency between mortality and risk factors. ${ }^{1}$ For instance, the association between smoking and mortality may be studied. A high degree of correlation has been shown between the incidence rates for cancer of the lung in 1974-80 and smoking habits in the Swedish counties and large towns in $1963 .{ }^{33}$ In both the 1960 s and 1980s smoking rates were high in the large towns, ${ }^{3334}$ where there were high death rates for cancer of the trachea, bronchus, and lung in the period 1974-1985..$^{1726}$ When analysing at the community level, however, it is important to be aware of the limitations due to the potential for ecological fallacy. ${ }^{1}$

For cancer of the cervix, both the systematic components of variation were significant. The variation in death rates was not fully explained by variation in the incidence rates of invasive cancer. Other explanations should be sought, such as variation in the effects of health care intervention for early diagnosis and treatment. ${ }^{1314}$

Other studies have shown the influence of cervical screening on trends and national variations in mortality outcome..$^{3536}$ Organised screening programmes were introduced at different times in the different counties of Sweden in the 1960s and 1970s. ${ }^{35}$ It would thus be of interest to study the relation between screening activities and the systematic components of variation in death rates from cervical cancer.

The systematic variation in mortality may also be dependent on the stage of the disease reached at diagnosis and at the start of treatment ${ }^{3738}$ and the case survival and case fatality rates. ${ }^{31} 32$ In survival studies the course of individual cases may be analysed. Regional variation in cancer patient survival can also be studied. ${ }^{39}$

There has been a debate on how progress against cancer should be measured. Bailar and Smith consider the best single measure to be the changes in the age adjusted mortality rate, while the incidence rates and survival rates could be affected more by changing standards of diagnosis. ${ }^{40} \mathrm{~A}$ systematic earlier diagnosis will also tend to increase case survival rates even in the absence of higher cure rates as a result of lead time bias. ${ }^{41}$ Adami et al have argued that these effects are only marginal in Sweden. ${ }^{31}$

It is important to stress that measuring incidence adjusted systematic variation in mortality does not solve the problem of separating the effects of earlier diagnosis from the effects of improved treatment. Incidence and mortality data are, however, more easily available than data on survival rates.

The potential bias in cancer incidence and mortality data in Sweden is considered to be small in the age groups studied. ${ }^{21-222431}$ The diagnostic validity is, however, another important area for the analysis of possible explanations of systematic small area variation in incidence and mortality.

During the 1970s and 1980s the idea of studying avoidable mortality as an indicator of the quality of care was developed. Medical technology is characterised by rapid progress, with new treatments being continually introduced for different diseases. The selection of useful indicators of avoidable mortality could, thus, differ when applied to different time periods and countries. Furthermore, analysis of different systematic components of variation in death rates should be useful when indicators for further studies on the quality of care are selected.

The author thanks Professor Björn Smedby, Uppsala for his support, Professor Gunnar Eklund and Professor Adam Taube, Uppsala for statistical advice, and Professor Claes-Göran Westrin, Uppsala for his comments. The study was supported by the Swedish Planning and Rationalization Institute for Health and Social Services (Spri), Stockholm.

1 Rosén M, Nyström L, Wall S. Guidelines for regiona mortality analysis: an epidemiological approach to health mortality analysis: an epidemiological app

2 Walter SD, Birnie SE. Mapping mortality and morbidity patterns: an international comparison. Int $\mathcal{f}$ Epidemio 1981;20:678-89.

3 Diehr P. Small area statistics: large statistical problems. $\mathrm{Am}$ f Public Health 1984;74:313-4.

4 McPherson K, Wennberg JE, Hovind OB, Clifford P. Smallarea variations in the use of common surgical procedures: an international comparison of New England, England, and Norway. $N$ Eng $\mathcal{f}$ Med 1982;18:1310-14.

5 Diehr P, Cain K, Conell F, Volinn E. What is too much variation? The null hypothesis in small-area analysis. Health Serv Res 1990;24:741-71.

6 Paul-Shaheen P, Deane Clark J, Williams D. Small area analysis: a review and analysis of the North American literature. $f$ Health Polit Policy Law 1987;12:741-808.

7 Weiss KB, Wagener DK. Geographic variations in US Asthma mortality: small-area analyses of excess mortality,

1981-1985 Am J Epidemiol 1990;132(suppl 1):107-15.
8 Hole DJ, Lamont DW. Problems in the interpretation of small area analysis of epidemiological data: the case of cancer incidence in the West of Scotland. $\mathcal{F}$ Epidemiol Community Health 1992;46:305-10.

9 Willemain TR. On the comparison of highest and lowes surgery rates in small-area studies. In: Rothberg D, ed. Regional variation in hospital use. Lexington MA; Lexington Books, 1982;91-100.

10 Mackenbach JP, Bouvier-Colle MH, Jougla E. "Avoidable" mortality and health services: a review of aggregate data studies. $¥$ Epidemiol Community Health 1990;44:106-11.

11 Charlton JRH, Hartley RM, Silver R, Holland WW. Geographical variation in mortality from conditions amenable to medical interventions in England and Wales. Lancet 1983;i:691-6.

12 Bauer RL, Charlton JRH. Area variation in mortality from diseases amenable to medical intervention: the condiseases amenable to medical intervention: the con-
tribution of differences in morbidity. Int $\mathcal{F}$ Epidemiol 1986; tribution of

13 Holland WW, ed. European Community atlas of avoidable death. Oxford: Oxford Medical Publications, 1988. Commission of the European Communities Health Service Research Series no. 3.

14 Holland WW, ed. European Community atlas of avoidable death. 2nd ed Vol 1. Oxford: Oxford Medical Publications, 1991. Commission of the European Communities Health Services Research Series No 6.

15 Ruttstein DD, Berenberger W, Chalmers TC, Child GC Fischmen AP, Perrin EB. Measuring the quality of medical care. N Engl f Med 1976;294:582-8.

16 National Board of Health and Welfare. Cancer incidence in Sweden. Stockholm: The Cancer Registry, 1968-1985 (yearly reports)

17 Dödsorsaker (Causes of death). Stockholm: National Central Bureau of Statistics 1974-1985 (yearly reports). (In Swedish, summary in English).

18 Westerling R. "Avoidable" causes of death in Sweden 1974 85. Quality Assurance in Health Care 1992;4:319-28.

19 Survival of cancer patients. Cases diagnosed in Norway 1968 75. Oslo: The Cancer Registry of Norway, 1980.

20 Vågerö D, Persson G. Cancer survival and social class in Sweden. $\mathcal{f}$ Epidemiol Community Health 1987;41:204-9.

21 Mattson B. Cancer registration in Sweden. Studies on completeness and validity of incidence and mortality registers. University of Stockholm, 1984. Thesis.

22 Betänkande av cancerkommittén. Cancer, orsaker, förebyggande $\mathrm{mm}$. Stockholm: SOU 1984:67. (Cancer, causes, prevention etc. Report from the Swedish Cancer Committé, In Swedish).

23 Britton M. Diagnostic errors discovered at autopsy. Acta Med Scand 1974;196:203-10.

24 deFaire U, Friberg L, Lorich U, Lundman T. A validation of cause-of-death certification in 1156 deaths Acta Med of cause-of-death $1876 ; 200: 223-8$.

25 Armitage P, Berry G. Statistical methods in medical research. 2nd ed. Oxford and Edinburgh: Blackwell Scientific Publications, 1987 .

26 Breslow NE. Extra-Poisson variation in log-linear models. Applied Statistics 1984;33:38-44. 
27 Baker RJ, Nelder JA. The GLIM system. Release 3 manual. Oxford: Numerical Algorithms Group, 1978.

28 SAS Institute Inc. $S A S$ user's guide: statistics. Version 5 edition. Cary, NC: SAS Institute Inc, 1985.

29 Westerling R. Indicators of avoidable mortality in health administrative areas in Sweden 1974-1985. Scand $\mathcal{F}$ Soc Med 1993;21:176-87.

30 Amler RW, Dull HB eds. Closing the gap. The burden of unnecessary illness. Oxford: Oxford University Press, 1987.

31 Adami HO, Sparén P, Bergström R, Holmberg L, Krusemo UB, Pontén J. Increasing survival trend after cancer diagnosis in Sweden: 1960-1984. F Natl Cancer Inst 1989;21: 1640-7.

32 Walker A, Petruckevitch A, Bourne H, Burney P. Contributions of incidence and case fatality to mortality from bladder cancer in the south Thames regions. $\mathcal{F}$ Epidemiol Community Health 1992;46:387-9.

33 Eklund G. Carstensen J. Cancer incidence in Sweden 1959 1980. A geographic evaluation. In: Cancer incidence in Sweden. Stockholm: The cancer registry, National Board Sweden. Stockholm: The cancer regist
of Health and Welfare, 1983:77-82

34 Rosén $M$, Hanning $M$, Wall $S$. Changing smoking habits in Sweden: towards better health, but not for all. Int $\mathcal{f}$

Epidemiol 1990;19:316-22.
35 Pettersson F, Björkholm E, Näslund I. Evaluation of screening for cervical cancer in Sweden: trends in incidence and mortality 1958-1980. Int f Epidemiol 1985;14:521-7.

36 Läärä E, Day NE, Hakama $M$. Trends in mortality from cervical cancer in the nordic countries: association with organised screening programmes. Lancet 1987; 1247-9.

37 Gonella JS, Hornbrook MC, Louis DZ. Staging of disease. A case mix measurement. $\mathcal{F} A M A$ 1984;251:637-44.

38 Gonella JS. Louis DZ, McCord JJ. The staging concept an approach to the assessment of outcome of ambulatory care. Med Care 1976;14:13-21.

39 Karhalainen S. Geographical variation in cancer patient survival in Finland: chance, confounding, or effect of treatment? F Epidemiol Community Health 1990;44:210-14.

40 Bailar JC, Smith EM. Progress against cancer? $N$ Engl $\mathcal{f}$ Med 1986;314:1226-32.

41 Enstrom JE, Austin DF. Interpreting cancer survival rates. The available data on survival are not a sensitive measure of progress in cancer control. Science 1977;195:847-51. 